\title{
Membangun kesadaran lingkungan melalui ekopedagogik pada anak usia dini berlandaskan konsep Jan Ligthart
}

\author{
Rd. Roro Windy Amelya Kusumawardani, Kuswanto \\ Universitas Pendidikan Indonesia, Kampus Cibiru \\ Jl. Pendidikan No.15, Cibiru Wetan, Cileunyi, Bandung, Jawa Barat, Indonesia \\ E-mail: windyamelya@upi.edu
}

\begin{tabular}{ll}
\hline \hline ARTICLE INFO & ABSTRACT \\
\hline \hline Article history: & Jan Ligthart merupakan salah satu tokoh yang berjasa dalam dunia pendidikan. \\
Received: $26-05-2020$ & Konsep yang ia gunakan dalam pendidikan ialah pendidikan alam sekitar atau \\
Revised: $10-06-2020$ & pendidikan yang berbasis alam. Adanya studi ini diharapkan bisa meningkatkan \\
Accepted:20-06-2020 & $\begin{array}{l}\text { kesadaran lingkungan pada anak usia dini melalui ekopedagogik yang } \\
\text { berdasarkan kepada teori Jan Ligthart agar anak usia dini mempunyai pondasi }\end{array}$ \\
Keywords: & yang kokoh untuk kehidupannya kelak. Penelitian ini merupakan penelitian \\
ekopedagogik, kesadaran & deskriptif kualitatif yaitu penelitian yang mengumpulkan data beserta fakta-fakta \\
lingkungan, anak usia dini & yang ada dari berbagai sumber. Hasilnya dari penelitian ini yaitu ternyata adanya \\
& kesadaran lingkungan pada anak usia dini sangat penting. Namun, masih ada pula \\
& hambatan yang terjadi yaitu kurangnya kesadaran pendidik dalam memahami \\
& ekopedagogik. Hal ini dilakukan untuk membahas masalah pentingnya anak usia \\
& dini mengenal serta mencintai lingkungannya tetapi bukan hanya melalui transfer \\
of knowledge melainkan adanya implementasi langsung ke lapangan.
\end{tabular}

Jan Ligthart is one of the figures who contributed in the world of education. The concept he uses in education is the education of natural surroundings or education based on nature. The existence of this study is expected to increase environmental awareness in early childhood through ecopedagogics based on Jan Ligthart's theory so that early childhood has a solid foundation for future life. This research is a qualitative descriptive study, a research that collects data and facts from various sources. The results of this study are in fact the existence of environmental awareness in early childhood is very important. However, there are still obstacles that occur, namely the lack of awareness of educators in understanding ecopedagogics. This is done to discuss the issue of the importance of young children to know and love their environment but not only through the transfer of knowledge but the implementation directly into the field.

\section{PENDAHULUAN}

Perkembangan zaman yang semakin maju dan pendidikan yang semakin berkembang sudah menjadikan manusia melupakan lingkungan sekitarnya, entah itu keluarga, teman maupun alam. Pendidikan saat ini kebanyakan lebih condong terhadap nilai intelektual yang bersifat objektif sehingga yang lebih dihargai pada saat ini ialah angka dibandingkan perkembangan peserta didik itu sendiri. Padahal, perkembangan peserta didik lebih penting dibandingkan nilai yang bersifat objektif. Nilai yang bersifat objektif hanyalah bonus yang diberikan dari perkembangan peserta didik.

Seorang tokoh pendidikan di Dunia, Jan Ligthart merupakan tokoh yang memiliki pemikiran yang berbeda dan beliau pun menentang teori yang sudah ada. Beliau lebih mengedepankan nilai-nilai subjektif dan pembelajaran yang terjun langsung ke lapangan tanpa harus banyak mendengarkan teoriteori yang dianggap akan membuat peserta didik menjadi pasif. Konsep yang diusung oleh Jan Ligthart ini berkesinambungan dengan konsep ekopedagogik yang sama-sama mengusung tentang lingkungan. Dengan adanya konsep ekopedagogik diharap pendidikan saat ini bisa mencintai lingkungan alam agar tidak terjadi ketimpangan antara manusia dengan alam. Maka dari itu, hubungan antara keduanya harus dibangun dengan baik. 
Konsep Jan Ligthart berkaitan dengan adanya pendidikan karakter yaitu usaha sadar manusia untuk mengembangkan nilai-nilai kebaikan dalam rangka memanusiakan manusia agar dapat memperbaiki karakter dan memberikan manfaat kepada lingkungan sekitar (Mustoip, Japar dan Zulela, 2018) pendidikan karakter harus dibarengi dengan adanya partisipasi aktif dari siswa untuk berpartisipasi dalam lingkungan sekitarnya (sekolah). Selain itu harus adanya dukungan dari guru sebagai motivasi anak agar bisa menjadi lebih maju dan membimbing anak kejalan yang benar. Membimbing anak bukan hanyalah persoalan guru, melainkan orang tua pun menjadi peran penting untuk menstimulasi perkembangan anak melalui pendidikan karakter. Apabila salah satu pihak tidak menjalankan perannya, maka akan terdapat ketidakseimbangan atau kurang sempurnanya pendidikan karakter.

Jan Ligthart adalah seorang tokoh pendidikan yang berasal dari Amsterdam, Belanda. Beliau dilahirkan pada tanggal 11 januari 1859 oleh orang tua nya yang sederhana. Ibunya yang menjadi pahlawan untuknya karena selalu mencukupi kebutuhan hidupnya, karena itulah beliau sangat menyayangi ibundanya. Beliau merupakan guru dan ahli pendidikan yang terpandang di Belanda. Beliau pun pernah menjabat sebagai kepala sekolah Granvenhage pada tahun 1855 hingga beliau wafat. Beliau banyak menuliskan karya tulis seperti buku, majalah, artikel tentang pendidikan. karyakarya yang dituliskannya bersama kawannya antara lain De Wereld In dan Het Volle Leven dan Salah satu buku yang terkenal ialah berjudul (kenangan-kenangan masa kecil) jika diterjemahkan kedalam bahasa Indonesia. Beliau pun wafat karena peristiwa tenggelam dalam air.

Dasar-dasar pemikiran Jan Ligthart antara lain yaitu pembelajaran barang yang sesungguhnya. Tujuan pendidikan yang dikemukakan ialah untuk membantu peserta didik memiliki nilai moral atau budi pekerti yang tinggi, sehingga bukan hanya cerdas di otaknya saja, melainkan juga bagus dalam berperilaku. Kata hati pun menjadi dasar pemikiran beliau tujuannya agar tertanam rasa saling memiliki, menyayangi, mengasihi antar sesama peserta didik dengan pendidik. Yang ketiga ialah metode buah limau yang dimaksud dengan mengalahkan keburukan anak dengan perbuatan baik dan sumber utama yang beliau ambil ialah sumber daya alam untuk menunjang seluruh aspek pembelajaran. Beliau pun termasuk tokoh yang tidak menyetujui dengan adanya bentuk pembelajaran yang intelektualisme (mementingkan intelek anak) dan verbalism (lebih banyak mendengarkan) maka dari itu beliau mengusung pembelajaran dengan cara meperagakan melalui barang yang sesungguhnya.

\section{METODE}

Penelitian ini adalah penelitian deskriptif yang menggunakan metode kualitatif yang bersifat lliterature review dalam pengambilan data. Langkah yang digunakan untuk mengambil data adalah dengan membaca teks buku, mencari jurnal yang sejalan dengan studi ini dan yang terakhir dengan cara menganalisis hasil yang telah didapatkan dari buku, jurnal atau pun penelitian yang sejalan.

\section{HASIL DAN PEMBAHASAN}

\section{Hasil}

Bumi saat ini sudah menua, banyaknya lingkungan alam yang rusak bukan semena-mena karena faktor alam saja melainkan karena adanya campur tangan manusia di dalamnya. Hal ini sudah di jelaskan dalam Al-Qur'an bahwa "Telah nampak kerusakan di darat dan di laut disebebakan karena perbuatan tangan manusia, supaya Allah merasakan kepada mereka sebagian dari akibat perbuatan mereka, agar mereka kembali kepada jalan yang benar (Q.S Ar-Ruum: 41). Sejalan dengan hal itu (Murdiati: 2013) memaparkan bahwa tindakan manusia yang cenderung melampaui batas dalam pemanfaatan potensi alam dapat mengakibatkan kerusakan dan menuai bencana. Sudah jelas tertera di dalam kitab suci artinya ini menjadi tantangan tersendiri untuk seluruh manusia terutama guru agar bisa menghasilkan murid-murid yang cinta terhadap lingkungannya dengan melakukan hal kecil tetapi memiliki seribu makna. Kualitas seorang anak dapat dinilai dari proses tumbuh kembang. Proses tumbuh kembang merupakan hasil interaksi faktor genetik dan faktor lingkungan Sejalan dengan adanya permasalahan tersebut konsep Jan Ligthart bisa menjadi salah satu cara untuk mengubahnya, karena konsep ini sangat condong kepada pembelajaran lingkungan. Konsep yang dikembangkan oleh 
Ligthart ini dapat mendukung adanya konsep ekopedagogik di Indonesia. Menurut Septiani, N (2018), lingkungan alam merupakan salah satu komponen terpenting dalam pengembangan tujuan, isi dan proses pendidikan pada anak usia dini. Esensi tujuan pendidikan pada anak usia dini diantaranya adalah membantu anak memahami dan menyesuaikan diri secara kreatif dengan lingkungannya.

Sumber utama yang digunakan ligthart adalah sumber daya alam, sumber ini bisa mempermudah gerakan akademik untuk menyadarkan peserta didik akan pentingnya lingkungan sehingga peserta didik dapat memiliki kesadaran, pemahaman dan kecintaan terhadap lingkungan sesuai dengan pengertian konsep ekopedagogik. Untuk mewujudkan generasi penerus bangsa yang memiliki kesadaran, pemahaman dan rasa cinta terhadap lingkungan harus dimulai sejak dini. Pendidikan awal merupakan pendidikan yang mengarah pada usia 0 hingga 6 tahun, pada usia ini anak sedang mengulik terhadap apa saja yang berada di lingkungannya. Tidak menutup kemungkinan bahwa usia ini menjadi usia yang memiliki penyerapan ilmu paling cepat kedalam otak. Karena itulah sudah sepatutnya untuk menstimulus usia tersebut dengan hal-hal yang positif guna menjadi pondasi untuk kehidupannya di masa depan, dengan membangun pembiasan dasar seperti melalui sekolah dengan lingkungan berbasis alam atau back to nature pemikiran ini sejalan dengan pemikiran Rousseau. Bagi Rousseau untuk selamat dari masalah tersebut, maka jalan satu-satunya adalah back to nature (Darmawan, 2016). Selain itu, pendidikan dasar yang paling utama untuk mengembangkan karakter ialah melalui Pendidikan Anak Usia Dini (PAUD). Sebagian orang meremehkan, namun sejatinya pendidikan inilah yang paling penting. Pembelajaran dari lingkungan oleh Jan Ligthart dibagi menjadi tiga yaitu, lingkungan alam sebagai bahan mentah, lingkungan produsen atau lingkungan pengrajin sebagai pengolah dan penghasil bahan mentah menjadi bahan jadi serta lingkungan masyarakat pengguna bahan jadi. Bahan ini bisa dijumpai di lingkungan kita sehari-hari seperi batu, tanah, daun, tanaman, sungai, peternakan dan kebun

Sehubungan dengan hal tersebut, sesuai dengan model pendidikan pembelajaran barang sesungguhnya, terdapat langkah yang harus dilewati yaitu: 1) Menemukan sesuatu yang menjadi pusat anak. untuk menemukan pusat anak bisa dilakukan dengan cara menemukan bahan pembelajaran yang terdapat di lingkungan sekitar anak lalu ke lingkungan yang terjauh. Contohnya seperti buah-buahan, umbi-umbian; 2) Melakukan studi wisata. Pada tahap ini guru mengajak peserta didik untuk pergi ketempat yang memang menjadi pusat anak, seperti kebun yang penuh dengan bunga bunga atau sungai yang penuh dengan bebatuan, dnegan melihat kondisi lingkungan sekitar, anak akan memiliki spontanitas untuk bertanya kepada guru semisalnya "ibu, mengapa banyak ikan di sungai?" hal itu akan menjadi komunikasi yang positif untuk mengembangkan kemampuan verbal dan kemampuan intelektualitas secara berbarengan. Menurut Ahyani dan Astuti (2018), tahap ini sesuai dengan ciri masa kanak-kanak awal yaitu usia menjelajah lingkungannya dengan cara bertanya; 3) Pembahasan hasil pengamatan. Setelah terjun langsung ke lapangan, pada saat dikelas kita mengulang kembali apa yang sudah ditemukan pada saat itu dan diamati anak melalui gambar-gambar; 4) Menceritakan lingkungan yang diamati. Setelah anak mengamati, guru harus menceritakan kembali kondisi yang ada di lingkungan tersebut dan memberitahu sikap dan tindakan apa yang harus diperbuat oleh peserta didik; dan 5) Kegiatan ekspresi. Kegiatan yang terakhir ialah mengekspresikan apa yang sudah peserta didik lihat dengan memberikan tugas seperti mewarnai, menggambar serta menirukan gerak-gerik orang yang diamati.

\section{Pembahasan}

Pada saat ini pun banyak penelitian yang membahas tentang urgensi lingkungan yang sejalan dengan teori Jan Ligthart. Seperti pada judul "Kegiatan bermain berbasis art craft bagi anak usia dini untuk mempromosikan kecintaan pada lingkungan oleh Hayati N, Seriati N.Y dan Nurhayati, L (2012). Penelitian ini mengemukakan bahwa dengan menyusun pedoman permainan kreatif berbasis art craft bisa menumbuhkan kepedulian dan rasa cinta lingkungan pada anak usia dini karena dengan adanya permainan art craft bisa menumbuhkan rasa kreativitas dengan cara mengelola bahan yang ada di lingkungan yang sudah terpakai. Untuk mendukung adanya ekopedagogik ini pada pembelajaran dan kegiatan bermain di Pendidikan Anak Usia Dini (PAUD), dapat menggunakan kegiatan bermain berbasis art craft. Pendidik dituntut untuk bisa menggunakan atau memanfaatkan bahan-bahan yang berada di lingkungan seperti dedaunan kering yang dikreasikan menjadi hiasan yang dipasang di figura, botol bekas yang dapat dimanfaatkan menjadi tempat pensil atau pot tanaman, batang tanaman 
yang sudah potong dari pohonnya bisa dikreasikan untuk membuat pohon palsu. Kegiatan tersebut selain dapat menciptakan kecintaan terhadap lingkungan, tetapi bisa juga mengasah pola pikir serta kreativitas anak usia dini. Menurut Hayati N, Seriati N.Y dan Nurhayati, L (2012) terdapat beberapa permainan art craft yang dapat dipaparkan sebagi berikut. Pertama yaitu permainan dengan cara teknik menyusun dan mengkrontruksi benda. Kedua, membuat denah kolase. Ketiga, permainan yang dibuat dengan teknik memotong dan menempel. Keempat, permainan dengan teknik membutsir dan yang terakhir adalah dengan cara memahat. Hal ini menjadi salah satu cara menstimulus anak usia dini agar agar aspek perkembangannya dapat berkembang dengan sempurna dan baik selain dengan aspek perkembangan yang menonjol adapula kecerdasan ekologis yang muncul pada diri anak.

Kecerdasan ekologis terdapat tiga komponen yang mendukung yaitu adanya pengetahuan, kesadaran dan aplikasi agar mampu menjaga dan melestarikan lingkungan. Untuk mencapai kecerdasan ekologis ada pengimplemetasian ekopedagogik yang harus dijalani. Menurut Herlambang (2018), tahap yang pertama yaitu dengan adanya kegiatan pembelajaran yang mendukung nilai dalam kesadaran melalui pendekatan atau cara-cara yang ada seperti melalui transformasi nilai kesadaran lingkungan dengan pengenalan dan pemahaman melalui integrasi. Kedua, transaksi nilai kesadaran lingkungan melalui penerimaan komunikasi yang sifatnya dialogis. Ketiga, transinternalisasi nilai kesadaran lingkungan melalui penanaman sikap mental dan kepribadian melalui pembiasaan dan keteladanan peserta didik. Dengan adanya ketiga hal tersebut nantinya akan memunculkan kristalisasi nilai-nilai kesadaran lingkungan dan anak usia dini akan melalukan aktualisasi dan penerapan kepada dirinya sendiri.

Putri S,U dan Nikawanti, G mengutarakan "Pengenalan green behaviour melalui ecoliteracy pada anak usia dini" bahwa pengenalan lingkungan pada anak usia dini sangatlah penting. Dalam judul ini membahas bahwa perlu adanya pengenalan green behavior melalui ecoliteracy. Menurutnya, hal yang menarik dari pengenalan ini yaitu adanya hubungan manusia dengan alam sekitar adalah untuk menjaga kesimbangan ekosistem sehingga diharapkan dapat menjadi sebuah gaya hidup pada abad 21. Dengan adanya ecoliteracy pun harapannya bisa mendukung pengenalan green behaviour pada anak usia dini. Ecoliteracy yang dimaksud disini yaitu menanamkan sikap mencintai lingkungan dengan cara bercerita yang berhubungan dengan lingkungan. Adanya sikap mencintai lingkungan akan menumbuhkan green behavior atau prilaku yang bisa menjaga lingkungan dengan penuh kesadaran. Untuk menumbuhkan sikap mencintai lingkungan didukung dengan adanya identitas tempat yang berarti substruktur dari identitas setiap individu yang isinya ilmu-ilmu tentang lingkungan yang ia singgahi. Seperti anak usia dini yang distimulus di lingkungan sekolah berbasis alam dengan cara melakukan kegiatan yang menarik seperti melihat langsung hewan (ayam, bebek, ikan), bersentuhan langsung dengan tanah, air dan udara, melakukan cocok tanam, merapihkan sampah yang berada di lingkungan dan mereapkan pola hidup bersih di lingkungan agar didalam pemikiran mereka tertaman bagaimana ia harus memperlakukan lingkungan dengan semestinya. Hal ini sejalan dengan proses pendidikan yang dijelaskan oleh pedagogik kritis bahwa pendidikan itu bukan hanya transfer of knowledge melainkan transfer of value, dimana harus adanya pengaplikasian langsung kepada peserta didik agar peserta didik dapat melihat secara langsung bukti nyata di lapangan.

Herlambang (2018) mengemukakan berbagai acuan yang dapat digunakan dalam pengembangan bahan ajar. Yaitu tiga pilar ekopedagogik meliputi konsep kelenturan ekologi sosial, literasi budaya dan penggunaan teknologi secara kritis dan kreatif. membangun keseimbangan antara kemampuan berpikir (head), bersikap (heart) dan bertindak (hand) dan ketiga, mendorong pembelajaran sebagai proses sosial. Artinya, dalam hal Ini manusia tidak menjadi pemimpim yang ada di muka bumi ini, melainkan semua yang ada di muka bumi ini memiliki korelasi satu sama lainnya. Jadi, lingkungan dan manusia memiliki timbal balik yang saling menguntungkan. Ekopedagogik muncul karena adanya paradigma antroposentris dan krisis ekologi sehingga munculah pedagogik kritis yang berpemahaman bahwa lingkungan dan manusia memiliki hak yang sama sehingga munculah konsep ekopedagogik. Sejalan dengan yang dikatakan Herlambang, Dahlia (2014) mengutarakan hal yang hampir sama yaitu "Pendidikan anak usia dini berwawasan dan budi pekerti di Jogja Green School" dalam isunya menggunakan strategi dengan pendekatan lingkungan dan pembelajaran kontekstual. Dalam konsep ekopedagogik, dilakukan melalui berbagai strategi seperti konsep green school. Seperti penelitian yang dilakukan oleh Dahlia (2014), bahwa terdapat sekolah di Yogyakarta yang menerapkan lingkungan dan budi pekerti yang dinamakan sekolah Jogja Green School. Kegiatan sehari-hari yang dilakukan menggunakan bahan apa saja yang ditemui untuk 
dijadikan bahan pelajaran serta pembelajaran pun di arahkan dengan kejadian nyata di lingkungan sekitar sekolah. Seyogyanya, anak usia dini bukan hanya dinilai oleh penilaian objektif saja yang berupa angka satu hingga sepuluh atau bintang satu hingga bintang tiga, karena sekolah itu bukan hanya menciptakan kebanggaan karena nilai, tetapi membangun karakter kokoh untuk setiap individu.

Lingkungan memang sangat berpengaruh terhadap perkembangan. Menurut Widayanti (2015), terjadi hubungan secara timbal balik antara individu dengan lingkungan, tidak hanya faktor lingkungan yang mempengaruhi perkembangan sifat individu, namun individu tersebut juga mempengaruhi lingkungan sekitarnya. Dengan adanya ekopedagogik yang diterapkan dalam setiap paud nantinya akan menjadikan setiap anak memiliki kesadaran dan pemahaman yang kuat akan kecintaannya terhadap lingkungan. Berbagai upaya perlu dilakukan untuk mengembangkan aspek-aspek perkembangan anak dan lingkungan yang ada di sekitar merupakan salah satu sumber belajar yang menunjang pengembangan berbagai aspek perkembangan anak (Choiri, 2017).

Dengan adanya implementasi konsep yang bertemakan lingkungan, maka hal tersebut tersirat sebuah makna dari pendidikan karakter yang melalui tahapan moral knowing, moral feeling dan moral action. Moral knowing ialah pengetahuan moral yang memasuki ranah kognitif seperti mengambil sikap dan keberanian pengenalan diri. Pengetahuan ini dapat dilihat ketika anak bisa mengambil sikap seperti saat ia berbuat kesalahan ia meminta maaf. Moral feeling ialah penguatan dalam aspek emosi agar terbentuknya suatu karakter seseorang yang meliputi percaya diri, cinta kebenaran dan kerendahan hati Hal ini bisa dibuktikan pada konsep Ligthart bahwa anak berani bertanya secara spontan, mendeskripsikan apa yang ia lihat kepada gurunya. Moral action ialah hasil dari moral knowing dan moral feeling, dalam moral action ini anak harus bisa memenuhi tiga aspek antara lain kompetensi, keinginan dan kebiasaan.

\section{SIMPULAN}

Konsep pendidikan yang dikembangkan oleh Jan Lighart memiliki peran yang sangat penting untuk diimplementasikan dalam pendidikan di Indonesia. Hal ini sesuai dengan pendekatan pedagogik kritis bahwa terdapat tiga kesadaran yang berada di dalam mansyarakat, yaitu kesadaran magis dimana seseorang hanya manut saja dengan apa yang dibicarakan dengan orang lain, padahal tidak sesuai dengan dirinya serta masih percaya dengan hal-hal dahulu dan menerima takdir dengan begitu saja. Kesadaran naif yang mengetahui bahwa ada yang salah, tetapi tetap berdiam diri saja serta kesadaran kritis yang mencoba memperdalam masalah dan berani bertindak untuk membebaskan diri dari segala kebelengguan yang terjadi. Kita dituntut untuk memiliki kesadaran kritis dari konsep yang diusung Lightart agar guru bisa mengurangi model pembelajaran yang berisfat verbalism karena hal itu dianggap membuat anak menjadi pasif, padahal banyak cara untuk menstimulasi setiap aspek perkembangan anak usia dini dan diharapkan juga bagi peserta didik bisa berpastisipasi aktif agar dapat membantu tercapainya tujuan dari konsep pembelajaran ini. Terakhir, khususnya para orang tua agar dapat mendukung peran guru di sekolah untuk bisa menerapkan kembali pembelajaran di rumah supaya hasilnya bisa menjadi sempurna.

\section{UCAPAN TERIMA KASIH}

Alhamdulillah, artikel ini sudah dapat diselesaikan dengan baik. Pertama-tama saya ucapkan terimakasih kepada Allah SWT yang telah melancarkan saya dalam menyelesaikan artikel ini. Terimakasih pula saya sampaikan kepada bapak Kuswanto selaku dosen pedagogik UPI kampus Cibiru, teman-teman 2A PGPAUD UPI kampus Cibiru, orang tua saya, teman dekat saya yang sudah membantu dalam menyelesaikan arikel ini dengan baik. Semoga artikel ini dapat bermanfaat bagi semua kalangan. 


\section{DAFTAR PUSTAKA}

Ahyani, L, N. dan Astuti, R, D. (2018) Psikologi perkembangan anak dan remaja. Kudus: Universitas Maria Kudus.

Choiri, M, M. (2017). Upaya pemanfaatan lingkungan sekitar sebagai sumber belajar anak. Jurnal Refleksi Edukatika 8 (1).

Dahlia. (2014). Pendidikan anak usia dini berwawasan lingkungan dan budi pekerti di jogja green school. Tesis PGRA. UIN sunan kalijaga Yogyakarta.

Darmawan, I, P, A. (2016) "Pendidikan back to nature: Pemikiran jean jacques rousseau tentang pendidikan" Satya Widya 32 (1). 11-18.

Hayati, N., Seriati, N, N., dan Nurhayati, L. (2012). Kegiatan bermain berbasis art craft bagi anak usia dini untuk mempomosikan kecintaan pada lingkungan. Jurnal Kependidikan 42. (2). 152161.

Herlambang, Y, T. (2018). Pedagogik. Jakarta: Bumi Aksara.

Murdiati, E. (2013). Urgensi lingkungan hidup dalam Islam. Wardah 27.

Mustoip, S., Japar, M., dan Ms, Z. (2018). Implementasi pendidikan karakter. Surabaya: Jakad Publishing.

Putri, S,U dan Nikawanti, G. (2012). Pengenalan green behaviour melalui ecoliteracy pada anak usia dini.

PAUDNI, D. (2012). Pedoman: pendidikan karakter pada anak usia dini. Jakarta: Direktorat Jenderal PAUDNI.

Rahayu, G, D, S dan Setiyadi, R. (2018). Penerapan model project citizen dalam upaya meningkatkan kecerdasan ekologis. Mimbar Sekolah Dasar 5 .(1). 31-42.

Septiani, N. (2016). Penyelenggaraan pembelajaran berbasis alam guna mengembangkan karakter kepemimpinan (leadership) anak kelompok B di paud alam ungaran. Skripsi FIP UNNES. UNNES.

Sujiono, Y, N. (2013). Konsep dasar pendidikan anak usia dini. Jakarta: Indeks.

Widayanti, E. (2015). Pengaruh lingkungan terhadap tumbuh kembang psikososial anak klien di panti sosial bina karya sidomulyo Yogyakarta. Skripsi FDK UIN sunan kalijaga. Yogyakarta. 